\title{
IMPLEMENTATION OF DIGITAL LEARNING USING INTERACTIVE MULTIMEDIA IN EXCRETORY SYSTEM WITH VIRTUAL LABORATORY
}

\author{
${ }^{1)}$ Heru Setiawan; ${ }^{2)}$ Wiwi Isnaeni; ${ }^{3)}$ F. Putut Martin Herry Budijantoro; ${ }^{4)}$ Aditya Marianti \\ ${ }^{1,2,2,3), 4)}$ Semarang State University, Central Java, Indonesia \\ ${ }^{1)}$ herusetiawan@student.unnes.ac.id; ${ }^{2)}$ wi2isna@yahoo.co.id; ${ }^{3)}$ pututmartin@yahoo.com; \\ ${ }^{4)}$ tya.unnes@yahoo.co.id
}

\begin{abstract}
This study aims to: (1) develop an interactive multimedia with virtual laboratory in excretory system for senior high school students, (2) determine the eligibility of digital multimedia of excretory system, (3) determine the effectiveness of digital learning using interactive multimedia to improve students' achievement and activities using the excretory system. This research was conducted at Senior High School 1 Jepon, Blora, Indonesia for 2 months. The research approach was educational research and development including: (1)research and information collecting, (2) planning, (3) developing the preliminary form of the intended product, (4) preliminary field testing and validation of media by experts, (5) main product revision, (6)field testing, (7)operational product revision, (8) operational field testing, (9) final product revision, and (10) dissemination and implementation. The result is as follows: 1) the excretion system of virtual lab needs to be improved because of the inavailability of tools and limited materials, obselete school lab, expensive tools and lab materials, and crowded scheduling of laboratory uses; 2) digital multimedia of the excretory system with virtual lab is very eligible with outstanding criteria based on expert validation and field testing result; 3) digital learning using interactive multimedia improves students' achievement and activities, (tnumber of students who achieve the active criteria is $90.63 \%$ ).
\end{abstract}

Keywords: digital learning, interactive media, virtual laboratory, student's achievement, excretory system 


\section{Introduction}

Nowadays is a digital era. The era of technology should be utilized by teachers, especially in teaching biology, which is one of the science subjects which studies the natural surroundings immediately around students. However, some physiological material and invisible characteristics is often confusing for students to learn. According to Fischer (2008, p.67). There are some reasons why biological materials are considered difficult to learn, one of which is concerned with the instructional media that are used by the teachers.

According to Sugandi (2008, p.7), instructional media is an important tool that helps teachers in helping students under-stand biology materials. With global changes in the development of knowledge and technology primarily related to the education system in schools, teachers are required to develop media that make students learn the concept of biology more easily, but learning media today often get less attention from teachers (Virvou, Katsionis, \& Manos, 2005, p.6). When students open a package of high school biology textbooks that had been used, they will see a page full of many confusing words, with pictures that are too small and in need of clear zooming - all arranged in rigid layouts to maximize the space available. Not to mention the size of a thick book which means there will be more small-sized paper that must be addressed so that students quickly get bored and not motivated to learn.

On the other hand, today is a globalization era. The globalization is in various aspects of life and the field of education is no exception. Therefore, with the rapid advancement of information and communication technologies in education, learning is also directed to digitalization (digital learning). Digital learning is learning by utilizing digital media, electronic systems or computers so that they can support the ongoing learning process (Lazarowitz, 2013, p. 219).

Digital learning characteristics according to Adri (2007, pp.7-8) are: (1) The use of electronic technology; (2) taking advantage of computer (digital media and computer net- works); (3) the use of teaching materials that can be used independently (self-learning materials) which is then stored in computer, so it can be accessed by lecturers and students anytime and anywhere. Utilizing a schedule of learning, the curriculum, the results of the learning progress, and matters related to the administration of education can be viewed at any time on the computer.

Based on the interviews conducted to biology teachers of grade XI among schools in Indonesia, excretory system material is considered as being difficult for students. The difficult material is related to physiological processes which happen inside the body, so the physiological processes are invisible. This is evident from some students who have not yet reached the passing grade. Based on the results of a needs analysis by using a questionnaire, one of them is caused by less varied media used. It is known that teachers used instructional media in the material of the excretory system in the form of a text and visuals such as textbooks and modules, but students are less interested in the media and less active in learning so that they feel sleepy.

Based on the results of the questionnaire analysis of the teachers and students of 1 Jepon State Senior High School (SMAN 1 Jepon), all of the students want to study media at the excretory system, which are attractive, practical, easy to understand, convenient for viewing, stimulating to learn, easy to use, not easily damaged, and also containing complete material and the principles of scientific learning. The interactive learning media that can be used in learning are usually in the form of CD (compact disc) learning. It is rare to find a learning $\mathrm{CD}$ equipped with scientific-based content. The scientific approach in the teaching of biology should be designed and directed as much as possible to the involvement of students in constructing knowledge and skills of science through science processes which include observing, asking, reasoning, associating and communicating. For this purpose, a science laboratory is the most appropriate vehicle. However, the gaps that can be found in a laboratory used in school cannot be used with limited laboratory facilities. It is due to 
the the lack of science laboratory infrastructure in the educational institutions. The problems can restrict the development of higher order thinking skills and become a gap in SMA 1 Jepon, since the laboratory equipment and materials are limited. Based on the interviews with biology teachers in the school, the school already has a biology lab, but it does not yet have adequate facilities in the form of laboratory equipment and materials. It was due to the lack of funds. These problems made students unable to explore themselves and to do practical activities.

Based on the theory and the problems described before, media as a source of students' learning is made not only to become more attractive but it also has to be equipped with a complete materials-based on audiovisual, while the solution to the problems is the lack of laboratory infrastructure through virtual lab computer-aided simulation. A virtual lab allows hands-on and minds-on activities. Many researchers and practitioners believe that the technology of Virtual Reality (VR) has created new thinking in education. Duffy and Jonassen (1992) state that the technology in the world of education today should be based on the paradigm of constructivism. Sung and Ou (2002, p.180) report that the VR has the ability to facilitate learning activities. Under these conditions, an intractive $\mathrm{CD}$ including a virtual lab on the material needs to be developed as a learning medium for grade XI students.

The aims of this study are to: (1) develop an interactive multimedia with a virtual laboratory in an excretory system for senior high school students; (2) determine the eligibility of digital multimedia of an excretory system; (3) determine the effectiveness of digital learning using an interactive multimedia to improve students' achievement and student activities of excretory system.

\section{Method}

\section{Research Approach}

This research employed educational research and development (R\&D) approach, which is the process used to develop and validate an educational product which is developed, tested, and revised according to the results of the field testing (Borg and Gall (1983, p.20). The stages of the R\&D are (1) researching and information collecting, (2) planning, (3) developing the preliminary form of the product, (4) preliminary field testing, (5) main product revision, (6) main field testing, (7) operational product re-vision, (8) operational field testing, (9) final product revision, and (10) dissemination and implementation. In this study the $\mathrm{R} \& \mathrm{D}$ approach is used to produce materials based on scientific approach in excretory system.

\section{Time and Place}

This research was conducted at SMA N 1 Jepon from December 2014 to March 2015 in grade XI Semester 2 Academic Year $2014 / 2015$. This research was done only in the science class. SMA 1 Jepon is located on Blora-Cepu Street Km. 9 Blora, Central Java. The research subject for the field testing was 32 grade XI students. While the subject of the operation field testing was 64 grade XI students of Mia 2 and Mia 3.

\section{Research Procedures}

\section{Research and Information Collecting}

In this stage, data were collected to know the type of instructional media that had been used in SMA 1 Jepon and the need of the development of instructional media. The preliminary study used questionnaire, observation, interview and documentation. The subjects consisted of teachers and students. Teachers in this study was a teacher of Biology subject. The students used in this study were selected using random sampling method among those who have received excretory system material, which is 96 grade XII students, in the academic year 2014/2015.

\section{Planning}

In this stage, the development of instructional media was planned based on data from the needs analysis of the media obtained from research and information collecting which consists of making flowcharts and storyboards of digital interactive multimedia of excretion system, collection 
source material using some data, photos and video and animation from the book and internet. Media assessment criteria were adapted to the preparation according to the National Standards of Education Department of Indonesia with modifications to several aspects such as appropriateness of the content, appropriateness and eligibility of presenting language, formulation of learning objectives and indicators of achievement of competencies, as well as the preparation of the media. Developing an evaluation tool in the form of test instruments was aimed to measure the extent of students' understanding of the material that has been studied. The tests were performed using posttest.

\section{Development of Prelimenary Form of Product}

In this stage, a virtual lab was compiled. Virtual lab created that glucose test, urine protein test, physical and $\mathrm{pH}$ test, chloride test of urine. Tthe initial product of interactive digital multimedia excretory system was made as a whole using Adobe Flash Player ver. 5 .

The development of the initial format of products made with the following steps: (1) Preparing the materials that will be used to create media; (2) preparing media scipt; (3) editing the display of the main menu and its contents; (4) making the virtual lab design; (5) finishing program; (6) determing and manufacturing the specifications of the product; (7) preparing a virtual lab guide.

\section{Prelimenary Field Testing and Main Product Revision}

Validation phase includes validation of interactive digital multimedia in terms of appearance made by media experts and material expert. The aspects of media assessment in the form of software engineering aspect consists of usability, compatibility, reusablity, effectivity, and audio-visual aspects of communication, whereas the assessment of material aspects such as material scope, the material depth, and basic competencies and indicator linkages, and the aspects of language. While the questionnaire responses that provided to the media is directed to SMA 1 Jepon biology teacher and student.
Prelimenary field testing to validate the design was conducted by experts using a questionnaire of validation media. The media experts were two lecturers from the Department of Biology, who are the experts of Ecophysiology, from a well known university in Indonesia.

\section{Field Testing and Operation Product Revision}

Field testing was conducted on 32 students of class XI Mia 1. The tests were aimed to obtain information on the use of interactive digital multimedia learning in excretory system. testing is done by giving the media on students, then collecting the data through the questionnaire responses of students, as well as observation of activity and learning results are used to determine the level of student mastery. The method used is preexprerimental design. In this design before the sample is treated, first they are given a pretest then at the end they are given a post test. The student learning given a total of 4 meetings. Field testing was tested on 64 students. Assessment of the activities carried out by the observation of students during the learning process by the observer using observation sheets. The assessment of student's achievement is done after all learning process is completed using 30 multiple choice questions. Operation product re-vision is done based on the advice after testing a wide scale, then the media be improved to get the final product.

\section{Method of Collecting Data}

In collecting data, the following methods were employed: (1) Eligibility of interactive digital multimedia with criteria is taken by questionaire; (2) student and teach-er response data to interactive digital multimedia of excretion system were taken by questionnaire; (3) data of student student's achievement on the use of interactive digital multimedia system taken with excretion in learning tasks, virtual lab, and the final evaluation; and (4) data of student activity taken from the observation result to the student activity in teaching and learning by the observer. 
Data Analysis Methods

\section{Analysis of Expert Validation}

The data analysis expert judgment employed a Likert scale 1-4 (Wahono 2006, pp.45-46). The data were then calculated by the following formula:

$$
\mathrm{NP}=\frac{R}{S M} \times 100 \% \text {. }
$$

Note :

$\mathrm{NP}=$ the value of percent is sought

$\mathrm{R} \quad=$ score obtained

$\mathrm{SM}=$ maximum score

The categories of eligibility based on the percentage that is: $81 \% \leq \mathrm{NP}<100 \%$ (Outstanding), $62 \% \leq \mathrm{NP}<81 \% \quad$ (Very Good), $43 \% \leq \mathrm{NP}<62 \%$ (Good), 33\% $\leq \mathrm{NP}$ $<43 \%$ (Fair), NP $<33 \%$ (Poor).

\section{Analysis of Response Data of Students and Teachers}

The variable refers to the measure-ment scale (Likert scale) 1-4. The criteria for student and teacher responses to interactive digital multimedia excretory system are: $85 \%$ 100\% (Outstanding), 70\% -84\% (Very Good), 60\% -69\% (Good), 50\% -59\% (Fair), $<50 \%$ (Poor). The evaluation results were analyzed to determine the classical completeness with the classical criteria $\geq 80 \%$ of students meet the value individuals.

\section{Students Activity}

Activity data were obtained from observation sheets, then were analyzed in descriptive percentage. A percentage that has been obtained confirms the percention of student activity. The criteria classification according to the student's activity (Arikunto 2006 , pp. $60-61$ ) are: $85 \%-100 \%$ (very active), $70 \%-84 \%$ (active), 60\% -69\% (quite active), $50 \%-59 \%$ (underactive), $<50 \%$ (inactive).

\section{Findings and Discussion}

The Development of Interactive Digital Multimedia on the Material of Excretion Excretory System

\section{The Description of the Product}

Learning Multimedia in this study is in the form of learning CD. The development of interactive digital multimedia of excretion system in this study is the process of making media containing excretion system material, and a virtual lab designed specifically with the aid of electronic devices with the use of Macromedia Flash, through methods of Borg and Gall (1983, p.20).

In this study, the data are obtained from textbooks, electronics book, internet, high school biology syllabus. The data are used as source materials in the design of interactive digital multimedia. manufacture of virtual lab work is done by making the design tools and lab materials as real as possible. Design created allows the students can do the next step if the student clicked with appropriate tools. If students click practical tools and materials available in the virtual lab table to the right, lab work step will run automatically. So that the student assignment only make observations on the results of the virtual lab that they do. The physical test observe by students is the colour and acidity $(\mathrm{pH})$ test with universal indicator. While the glucose test students observe the color of urine before being tested benedict, after drops benedict color, color after being burned and the final color. At the stage of finishing media components, and virtual lab experiments need to be done repeatedly and improved many times that the media does not experience an error and can run smoothly from start to finish. Once the compilation is complete, the media creation is ready to be transferred into its application form. Interactive digital multimedia system measuring is $443 \mathrm{mb}$ (mega bytes). Minimal hardware used is a personal computer (PC) with these specs: Intel Pentium Dual Core 2.0 Ghz, 128 MB RAM, $150 \mathrm{MB}$ hard disk remnant, 1024 x 768 SVGA monitor, Windows XP, Windows Vista or Windows 7.

Preparation of modules guide in virtual lab and virtual lab report format for the students so that the students do not have difficulties when operated virtual lab uses the interactive digital multimedia of excretion system. This practical guide module is a kind of manual book, as an addition guidance to show the users how to operate the lab properly. The format of the student report is 
as follows: It should contain the column heading, the purpose, the basic theory, how to work, observations, data analysis and discussion, conclusions and references. The question should also equipped with critical thinking (contextual teaching and learning).

\section{Eligibility of Interactive Digital Multimedia on the Material of Excretory System}

Interactive digital multimedia eligibility was tested by two experts that is media experts and material expert (prelimenary field testing). The testing of the use was done by students and teachers in learning. The trial was conducted in two phases, namely, a limited scale (field testing) and large-scale trials (field operation testing).

\section{Prelimenary Field Testing}

The eligibility of interactive digital multimedia system based the validation of excretory material is presented in Table 1.

Table1. Eligibility of Digital Media Excretory System According to the Matter Experts

\begin{tabular}{lc}
\hline \multicolumn{1}{c}{ Aspects assessed } & Percentage \\
\hline Completed Material & $75 \%$ \\
Linkage core competency and base & $91.67 \%$ \\
competency of curriculum & $100 \%$ \\
The material accuracy & $90 \%$ \\
$\begin{array}{l}\text { Presentation of material } \\
\text { Communicative and interactive }\end{array}$ & $75 \%$ \\
$\begin{array}{l}\text { Aspects of language } \\
\text { Percentage eligibility of the material } \\
\text { in classical }\end{array}$ & $90.62 \%$ \\
\hline $\begin{array}{l}\text { The eligibility criteria in terms of material is } \\
\text { Outstanding }\end{array}$ & \\
\hline
\end{tabular}

Based on the eligibility assessment table, the multimedia of interactive digital excretory system has been eligible to be used as a medium of learning the material in classical eligibility percentage of $90.62 \%$ in an Outstanding criteria. The validation results in display media are presented in Table 2.
Table 2. Eligibility of Digital Interactive Multimedia of Excretion System According to Media Experts

\begin{tabular}{lc}
\hline \multicolumn{1}{c}{ Aspects assessed } & Percentage \\
\hline Software, usability & $100 \%$ \\
Audio and visual communication & $89.28 \%$ \\
Other aspects: the design of a & $87.50 \%$ \\
virtual lab & $91.17 \%$ \\
The percentage in the classical & \\
media eligibility & \\
\hline The eligibility criteria in terms of media Outstanding \\
\hline
\end{tabular}

Table 2 of the interactive digital multimedia in terms of media aspect judged four main aspects. Classically obtained by the percentage of $91.17 \%$ in Outstanding criteria.

\section{Main Product Revision (Revised Design / Product Early Stage 1)}

Revisions to interactive digital multimedia of excretion system was implemented based on recommendations and advice that given by media experts and material expert. Revision products based on expert input media which display the opening page, instructions for use, display, background, navigation buttons, distance between the main menu, sub menu simulation lab so that students know how practical procedures appropriate steps to correct. Meanwhile, revision by experts of material in the manual lab work on the simulation made slow motion, image support, legibility of text and graphics, simulation lab created flow charts, adding animations to clarify the mechanism, such as the formation mechanism of urine, the excretion of sweat, bile excretion, the formation of kidney stones, animation test results with biuret and benedict of diabetes mellitus disorder of urine. Display one expert revised the material before and after revison showed in figure 1 and figure 2. 


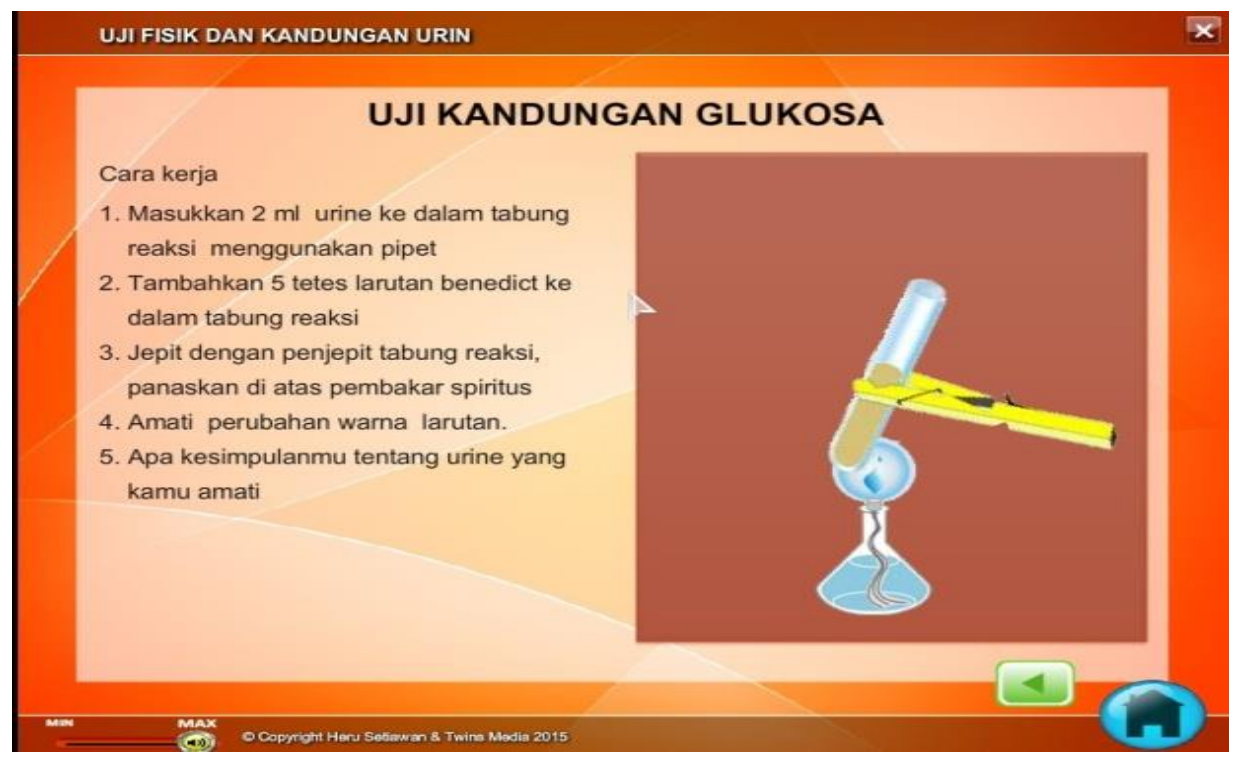

Figure 1. Simulation of Virtual Lab before Revision

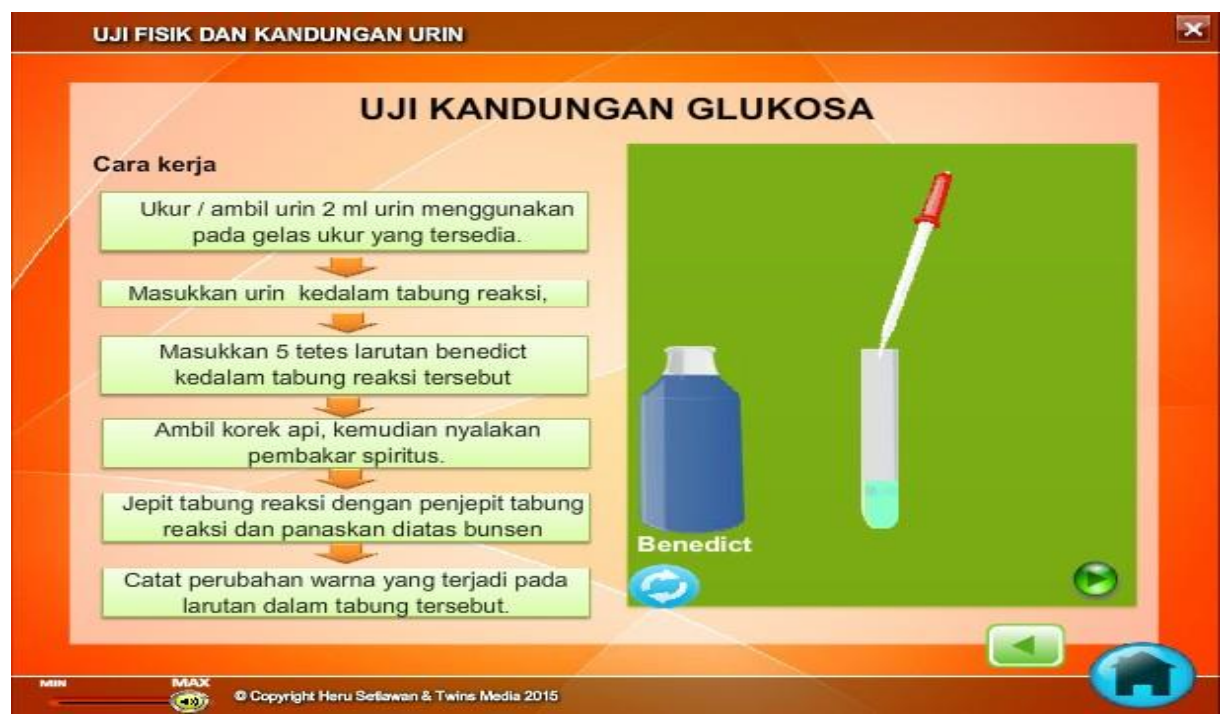

Figure 2. Simulation of Virtual Lab after Revision

Field Testing (Tests Media in Learning a Limited Scale)

Field testing was conducted to determine the effectivity of interactive digital learning media. The effectivity of interactive digital multimedia in excretory system in this research that the effectiveness of the activity and student's achievement. The field trials consist of a limited scale testing were carried out on 32 students of class XI Mia 1. Based on the results of research on a limited scale test is known that most of the students assess interactive digital multimedia system is Outstanding and very well criteria. The eligibility of interactive digital media excretion system on product testing (small scale) are presented in Table 3.

Table 3. Results of Student Responses to Interactive Digital Multimedia on a Small Scale Trial (Field Testing)

\begin{tabular}{lc}
\hline \multicolumn{1}{c}{ Response Criteria } & Percentage \\
\hline Outstanding & $84.38 \%$ \\
Very Good & $12.50 \%$ \\
Good & $3.13 \%$ \\
Fair & $0.00 \%$ \\
Poor & $0.00 \%$ \\
\hline
\end{tabular}

The questionnaire consists of 12 aspects such as readability, navigation buttons, the 
display, the clarity of the text / writing, language, becksound, virtual lab, aplicability of virtual lab in teaching and learning, and lso student interest to the media. Based on analysis of the responses items 100\% of students agreed learning using interactive digital multimedia is fun and not boring and urine lab simulation allows students to understand the physical test lab procedures and the content of the urine.

\section{Operation Product Revision}

Based on student responses to assessment of trials limited scale, needed some revisions. The revision is the main menu, audio settings (backsound). Settling material content in the form of points, as well as the revision of chloride test.

\section{Operation Field Testing (Trial Wide Scale)}

Large-scale trials are used to determine the response of students to instructional media after revision. Results of research student responses on large scale trials are presented in Table 4.

Table 4. The Response of Students to the Interactive Digital Multimedia of Large Scale Trials

\begin{tabular}{lc}
\hline Response Criteria & Percentage \\
\hline Outstanding & $92.19 \%$ \\
Very Good & $7.81 \%$ \\
Good & $3.13 \%$ \\
Fair & $0.00 \%$ \\
Poor & $0.00 \%$ \\
\hline
\end{tabular}

Based on these results it can be concluded that student responses increased which is compared to the limited scale trial. According to the students' response interactive digital multimedia systems facilitate the excretion of the physical and the content of the urine test, students are eager to learn, and learning to be fun and not boring.

Final Product Revision

Based on a broad scale trials there are still need some improvements to the media. Revisions were made only on the color of the urine into 3 colors, 3 colors of yellow urine, and urine 3 brownish yellow color. subsequently revised to green and blue colors more clearly visible and distinguishable.

\section{Results of Teacher Responses to Interactive Digital Multimedia of Excretion System.}

Teachers provide very good response $(95 \%)$ on the use of interactive digital multimedia excretion system. The problem for students who do not love music overcome by adding buttons for controlling the volume of music, so that it can be used according to user preferences. Constraints in implementing instructional media developed which takes longer before requiring preparation as well. This problem can be overcome with proper preparation before applying learning and improve time class management. The use of multimedia can help teachers deliver the material easily and effectively. This will suport student centered learning.

The effectiveness of interactive digital multimedia excretory system to improve student's achievement and student activity

The results of the study showed that learning using interactive digital multimedia system effective excretion on student's achievement and student activity, Which is presented in Table 5.

Table 5. Student's Achievement in a Limited Scale Trial (Field Testing)

\begin{tabular}{lll}
\hline $\begin{array}{c}\text { Classical } \\
\text { completeness }\end{array}$ & Graduate & $\begin{array}{c}\text { Not } \\
\text { Graduate }\end{array}$ \\
\hline Small scale test & $84.37 \%$ & $15.62 \%$ \\
Large-scale test & $87.5 \%$ & $12.5 \%$ \\
\hline
\end{tabular}

Based on the results obtained, we can conclude that learning using interactive digital multimedia effective to improve student's achievement. The effectiveness can be seen from the results of trials studying a limited scale or large-scale trials $\geq 75$. By definition presented study results is a combination of value assignment, virtual lab report, and the final evaluation. Classical mastery learning students with passing grade $\geq 75$ obtained on a limited scale trial of $84.37 \%$ and on a wide scale trial of $87.5 \%$. These percentages show that the student's achievement in learning 
using interactive digital multimedia system can achieve success indicators $\geq 80 \%$.

\section{The Trial Results of Interactive Digital Multimedia in Excretion System for Student Activities}

Based on trial results Multimedia interactive digital excretion system shown to increase the activity of students in learning excretion system. The effectivity can be seen from the results of the data analysis of a limited scale trial that showed that the activity of the students in the classical style for 3 sessions included in the criteria are very active and active as presented in Table 6.

Table 6. Activity of Students in Learning Using Interactive Digital Multimedia on a Limited Scale Trial

\begin{tabular}{lcc}
\hline \multicolumn{1}{c}{ Criteria } & $\begin{array}{c}\text { Activity on } \\
\text { small trial } \\
\text { testing }\end{array}$ & $\begin{array}{c}\text { Activity on } \\
\text { large trial } \\
\text { testing }\end{array}$ \\
\hline $\begin{array}{l}\text { Highly Active } \\
\text { Active }\end{array}$ & $34.38 \%$ & $39.06 \%$ \\
Active & $50.00 \%$ & $53.12 \%$ \\
Enough & $9.38 \%$ & \\
Less Active & $6.25 \%$ & $6.25 \%$ \\
Inactive & $0.00 \%$ & $3.13 \%$ \\
\hline
\end{tabular}

Based on the student's activity table, the number of students in the category of very active and inactive is $84.38 \%$, while $15.62 \%$ were the criteria of quite active and less active. This amount meets the minimum criteria of student activity in the classical style that is $\geq$ $81 \%$. For large-scale trial results during two meetings also shows the average percentage of student activity levels in classical $\geq 81 \%$ activity of students in learning activities including active and very active categories with a percentage of $92.19 \%$. While $9.38 \%$ were moderately active and less active.

One of the things that cause high student activity in learning is the learning done in groups. During the learning process of the students interact and work together to discuss the matter that exists in a media of learning. Discussion group also makes students more active and enthusiasm in learning. According to Amri and Ahmadi (2010, pp. 10-11) discussions help make lessons developed and stimulate the spirit of questioning and personal interests.
This is also supported by the interesting media, especially in the virtual lab. According to some students simulated virtual lab is very helpful in understanding the physical test lab procedures and the content of the urine. Learning environment is attractive and fun that facilitate students in learning, so will give result in the achievement of students' understanding of the material. Dani (2008, pp.10-12) revealed that interactive media is one of the tool in teaching for both students and teachers that are quite effective in helping teachers to deliver educational material so that the absorption of students is higher than the conventional way because: (1) students quickly absorb information and knowledge of the material presented, (2) pictures, video, and animation in the media more attractive than text, (4) interactive, and (5) oriented towards problem solving. According to the responses of teachers that used interactive digital multimedia facilitate the learning to achieve the goal, because in it there is complete coverage and interesting material. Arsyad (2011, p.12) suggests computer can accommodate students who are slow to accept the lesson because the use of multimedia involves various organs of the body begin to ear (audio), eyes (visual), and hand (kinaesthetic). The involvement of the various organs of this makes the information easier to understand. According to Istianda and Darmanto (2009), students were only able to retain $20 \%$ of what they seen, $30 \%$ of which they heard, but can remember $50 \%$ both they heard and seen and able to remember $80 \%$ of which is seen, heard and done at once. Moreover the effectiveness of interactive digital multimedia excretion system on student's achievement is also because the media can visualize material of excretory systems that are abstract and difficult to see directly. In line with the statement Adri (2007, pp.22-23) multimedia have special functions such as multimedia animation, simulation and visualization, students get a more real information than the information that is abstract so be able to develop the cognitive aspects. Same as the teacher, based on the advice that given, the teacher wants the other biological material is also made such learning 
CD Multimedia interactive digital excretion system, so that students are interested in learning. Learning to use interactive digital multimedia excretion system requires the presence of the teacher as a facilitator, because the interaction with the computer and humans have not been able to replace the human interaction with humans (Ismail, 2006, pp. 23-24). Most students complete the learning using interactive digital multimedia excretion system, even so there are still some students who have not completed. The factors that cause this are internal factors and external factor in students. On the application of multimedia $84.37 \%$ of students scoring above 75 or above passing grade, only $15.63 \%$ of the students are still getting the study under passing grade on a limited scale trial, and the large scale trial of $87.5 \%$ students completed, meaning that there is an increase compared to the limited scale trial. This shows that the multimedia application is effective in achieving good student's achievement. Multimedia is able to enhance the learning process and facilitate the process of communication between teachers and students as multimedia self-learning is able to create an atmosphere so that students have the ability to organize themselves and have the intrinsic motivation to learn the material of excretory system. Based on the data analysis is also known that the lab reports the average student is quite good, on a limited scale trial or to test a wide scale. Some students have been able to write a report well, ranging from the title, basic theories, tools and materials, work methods, data analysis and discussion, and conclusion. In addition the average student already answer the critical thinking question.

According to Mintz (1993, p. 13), one of the promising applications is the use of computer simulations to teach material that cannot be done by using conventional laboratory. However, is computer simulations as effective as conventional laboratory, or can it replace them? Several studies in more than two decades have shown that the use of computer simulations and lab practicum using conventional laboratory can effectively improve student's achievement. The answer is dependent on the concept and the situation (Cengis, 2010, p. 3). Concept in the sense of what kind of simulated virtual lab, if the simulated is the concept of science that really abstract so as to make the students very difficult to learn, or the concept occurs very slowly, too dangerous to do, then the use of virtual lab will be very effective. While the situation in terms of condition of the use of virtual lab is whether it is appropriate in the context of its use for example the condition of school laboratories, if the virtual lab is used in schools with very limited facilities virtual lab will be more effective than schools that have full facilities (Cengis, 2010, p. 4). In addition, the results in this study supported by several research studies e.g. Russell et al. (1999, p.335) and Sanger and Greenbowe (1997, p.821) showed that the increased proportion appropriate statement compared the proportion of misconceptions decline after use virtual animation lab. In addition, a related study shows that the computer with additional effects, such as animation, simulation, and positive votes in improving the quality of learning (Douglass, 1990, p. 46; Heerman, 1988, p.7). While Hutt (2006, p.40) found that the combination of simulation and laboratory benefits lab time so that time can be reduced. This is in line with the statement proposed by Redish, Jeffery, and Steinberg (1997, p.4) which reports that computers are used in teaching as a learning tool to make the process of instruction increase student motivation, provide benefits for students to learn independently and manage time they need based on their own learning speed.

Although the results of this study support that the use of virtual labs improve student's achievement and provide positive results for students in learning activities in biology subject, it is not claimed that the interactive digital multimedia of excretion system which is simulation-based laboratories are more effective than the activity of students in the real laboratory because the two were not examined and compared in this study. However, it is claimed that the creation of virtual lab is to show activity in the real laboratory as a reason for reaction to harmful chemicals, lab time constraints, limited equip- 
ment owned by the school lab, then in a state of virtual lab so they can be used as an alternative solution. However, in some studies as well as a research conducted by Karr et al (2004, pp.6-8) which in this case comparing the achievements of some students who guided using Hands-on Chemistry Lab compared with students who guided using the Virtual Chemistry Lab (eLab). They found that there was no difference between the segnificant achievement learn or gain score values between them. They commented on their findings that students taught using the Hands-on Lab Chemistry appeared as good as that taught using Virtual Chemistry Lab (eLab).

Learning using interactive digital multimedia of excretion system certainly has its advantages and disadvantages. According to Cengis (2010, pp.7-8), some advantages of virtual lab include: (a) Allowing convenient learning as tools and materials simulated in the virtual computer so that it is not too dangerous; (b) learners can learn and develop creativity to experiment easily; (c) the problem can be presented using the virtual computer to generate student motivation; (d) the need for students to learn will increase because it is presented with animation which is more interesting; (e) virtual laboratory does not necessarily require a long time to prepare and carry out the activity because it is presented on the computer; (f) can encourage learners to be more effective and active in the learning process; (g) the calculation results of the experimental data is more valid and precise so that it will be easier to obtain the concepts presented.

Meanwhile, the lack of assisted learning virtual laboratory are: (a) The success of virtual laboratory assisted learning relies on the independence of the student to follow the learning process; (b) the access to carry out virtual laboratory activities depend on the number of computer facilities which is provided by the school; (c) learners may feel bored if the lack of understanding about the use of the computer so that it can generate a passive response to conduct virtual experiments; (d) guidance is needed from the teacher before the experiment using virtual laboratory that carried out well; (e) less accordance with the process approach, particularly to aspects of students' skills, especially for kinesthetic skills.

According to the responses of teachers use interactive digital multimedia systems facilitate the excretion of the teacher in the learning process to achieve the expected goal, because in it there is complete coverage and interesting material. The material in instructional media already meet the core competency and basic competencies that must be achieved, in accordance with the development of science and technology, easy to understand, and the presentation and the language used is good. Excess medium of learning is to increase students' interest because they can show contextually particular physiological mechanisms of excretion system, the learning is not monotonous because it involves information technology and creating a variety of learning methods. Learning to use a medium increases students' independence is also the ability to use technology in learning. Students are dealing directly with a computer so as to provide a new experience for the students.

Interactive digital multimedia of excretory system can integrate several components such as sound, text, animation, pictures, videos and games. The multimedia integrate these components in order to optimize the role of the senses to receive information and store it in memory. In harmony with the opinion, Arsyad (2011, p.5) reveals that the use of multimedia involves various organs of the body, namely, ear (audio), eyes (visual), and hand (kinaesthetic). Although the interactive digital multimedia system has not been able to facilitate the excretion of student involvement in the hand (kinaesthetic) as a whole using the five senses as well as during the laboratory experiments, the kinesthetics which is meant is kinesthetics in operating computers. Such involvement of the various organs makes the information easier to understand.

Wahyuni and Kristianingrum (2008, p.8) also stated that interactive CD are applied in learning can improve student's achievement and the active role of students, because the 
students liked the atmosphere of the class that fun and not boring. The role of teachers in learning activities also contribute to the effectiveness of interactive digital learning media of excretion system. Teacher in the learning process more act as a facilitator and motivator that can provide convenience to students so that students can learn optimally, so that students truly become a center of learning and the teacher as a facilitator. Teachers facilitate students who want to ask if the student is not familiar with the material which is contained in the instructional media and students who do not understand the operation of instructional media. Students' incomprehension in the operation occurs due to the students' attention to the instructions for the use of instructional media.

Most students complete the learning using interactive digital multimedia of excretion system, even so there are still some students who have not completed. The factors that cause this are internal factors and external in students. Internal factors may be psychological factors that exist on students, such as, motivation, attention, concentration, comprehension and memory. Another cause is student's ability to think differently, and not all students are accustomed to use computers as learning media. On the application of multimedia amounted to $84.37 \%$ of students scoring above 75 or above passing grade, only $15.63 \%$, amounting to 8 students or students who are still getting the study under passing grade on a limited scale trial, and the large scale trial $87,5 \%$ of students completed, meaning that there is an increase compared to the limited scale trial. It shows that the implementation of multimedia is effective in helping students reaching good achievement. Multimedia is able to enhance the learning process and facilitate the communication process between teachers and students as selflearning multimedia is able to create certain atmosphere so that students have the ability to organize themselves and have the intrinsic motivation to learn the material excretory system. Hasebrook and Gremm (1999, p.5) suggests that multimedia can help students to enhance communication, motivation and selflearning ability.
Evaluation of Learning Using Interactive Digital Multimedia

In general, the implementation of learning using interactive digital media of excretory system can be implemented properly. However, in addition to the advantages already described in learning using interactive digital multimedia of excretion system, not every implementation went smoothly. It sometimes encountered some problems. The problems that occurred in the field is a result of the weaknesses of a lesson. In order to avoid constraints, then the weaknesses of a lesson must be overcome. After conducting the research, there is something to consider: Learning to use interactive digital multimedia of excretion system will run optimally when all the students could play themselves.

\section{Conclusions and Suggestions}

\section{Conclusion}

Based on the research findings, the following conclusions can be drawn: (1) Interactive Multimedia excretion system needs to be developed based on several facts, such as the availability of tools and materials are limited in school lab, or school lab is not possible to use, tools and expensive lab materials, scheduling time-intensive laboratory use, but is supported by facilities adequate laboratory for use in teaching based technology; (2) the interactive digital multimedia system developed excretion achieve outstanding criteria are used as a learning media for teaching excretory system. Get positive responses from teacher and students; (3) interactive digital multimedia effective to improve student's achievement and learning activities in the excretion system of high school students at grade XI.

\section{Suggestions}

Based on the results obtained, it can be given a few suggestions including: Schools are advised to further optimize the computer lab facilities already owned. Before conducting virtual laboratory students must first master the procedure works well. For the teachers need to be considered in managing the time 
to be good when using the virtual laboratory experiments because the activities require a relatively long time. For the next developer, image composition and design of products can be made more attractive in order to motivate students to learn concepts of biology.

\section{References}

Adri, M. (2007). Development strategy multimedia instructional design. Journal INVOTEK, I(VII), 1-9.

Arikunto, S. (2006). Fundamentals of educational evaluation. Jakarta: PT Bumi Literacy.

Arsyad, A. (2011). Learning media. Jakarta: Raja Grafindo Persada.

Borg, W.R., \& Gall, M.D. (1983). Educational research: An introduction (4th ed.). New York, NY: Longman.

Cengis. (2010). The effect of the virtual laboratory on the students' achievement and attitude in chemistry. Online International Journal of Educational Sciences, 2(1), 37-53.

Douglas, J.E. (1990). Visualization of electron clouds in atoms and molecules. Journal of Chemical Education, 67, 42-44.

Duffy, T., \& Jonassen, R. (Eds). (1992). Constructivism and the technology of instruction: A Conversation. Hillsdale, NJ: Lawrence Erlbaum.

Fischer, R.G. (2008). The Delphi method: A description, review, and criticism. Journal of Academic Librarianship, 4(2), 6470.

Hasebrook, J., \& Gremm, M. (1999). Multimedia for vocational guide: Effects of individualized testing, videos and photography on acceptance and recall. Journal of Educational Multimedia and Hypermedia, 8(4), 37-400.

Heerman, B. (1988). Teaching and learning with computers. San Francisco: Jossey-Bass.

Hutt, P. (2006). Virtual laboratories. Prog. Theor. Phys. Suppl, 164, 38-53.

Ismail, A. (2006). Education games (Being smart and cheerful with educational games). Yogyakarta: Pilar Media.
Istianda, D., \& Darmanto. (2009). Making multimedia for improving service learning. Journal of Open and Distance Education, 1(X), 11.

Lazarowitz, R., \& Penso, S. (1992). High school students' Difficulties in learning biology concepts. Journal of Biological Education, 26, 215-224.

Redish, F. E., Jeffery B.C. \& Steinberg R.N. (1997). The effectiveness of active engagement microcomputer-based laboratories. Maryland, MD: Department of Physiscs, University of maryland College Park.

Russell, J.W., \& Kozma, R.B. (1997). Use of simultaneous-syncronized macroscopic, microscopic, and symbolic representations to enhance the teaching and learning of chemical concept. Journal of Chemical Education, 74(2), 330334.

Sanger, M.J., \& Greenbowe, T.J. (1997). Students misconseptions in electrochemistry: Current flow in electrolyte solutions and the salt bridge. Journal of Chemical Education, 74(1), 819-823.

Sugandi, A. 2008. The theory of learning. Semarang: Unnes Press.

Sung, W.T., \& Ou, S.C. (2002). Learning computer graphics viartual reality using technologies based on constructivism: Case study of the webdegratot system. J. Interactive Learning Environment, 10(3), 177-197.

Virvou M., G. Katsionis, \& K. Manos. (2005). Combining Software Games with Education: Evaluation of its educational effectiveness. J. Educational Technology \& Society, 8(2), 54-65. Available in http://www.ifets.info/ [accessed in February 4, 2015].

Wahyuni, S., \& Kristianingrum, A. (2008). Improving student's achievement chemistry and the active role of students through PBI models with interactive CD media. Journal of Chemical Education Innovation, 2(1), 199-208. 